\title{
KESESUAIAN DAERAH PENANGKAPAN RAJUNGAN (Portunus pelagicus) MENGGUNAKAN ANALISIS SPASIAL PARAMETER LINGKUNGAN DAN HASIL TANGKAPAN DI PULAU LANCANG
}

\author{
Suitability Fishing Ground of Blue Swimming Crab (Portunus pelagicus) Using Environmental \\ Parameters Spatial Analysis and Catch Analysis at Lancang Island
}

\author{
Oleh: \\ Insaniah Rahimah ${ }^{*}$, Vincentius P. Siregar², Syamsul B. Agus ${ }^{2}$ \\ ${ }^{1}$ Sekolah Tinggi Perikanan dan Kelautan Matauli \\ 2 Departemen Ilmu dan Teknologi Kelautan, Fakultas Perikanan dan Ilmu Kelautan Institut Pertanian Bogor \\ * Korespondensi: insaniah.rahimah@gmail.com
}

Diterima: 22 Agustus 2016; Disetujui: 17 Oktober 2019

\begin{abstract}
The blue swimming crab in the waters of Lancang Island is indicated as being overfished. Hence, the major challenge is managing its utilization in a proper manner. The purpose of this study is to explore the water's characteristics which is suitable for blue swimming crab fishing. Accordingly, the potential fishing ground around Lancang Island waters can be mapped spatially as an initial effort for species preservation. Geospatial analysis was applied to assess the physical parameters of the existing habitat. The results show that parameters such as MPT, TDS, brightness, phosphate, nitrate, depth and substrate types were remarkably suitable to support the growth of blue swimming crabs. Meanwhile, parameters such as salinity, DO, and temperature show lower quality which implied that the habitat is less suitable. However, the result of weighting and reclassification conclude that Lancang island waters is a decent habitat for blue swimming crab. Catch data show that $40 \%$ blue swimming crabs have small carapace size $(7-11.83 \mathrm{~cm})$ which is undersized and prohibited by law. Furthermore, about $68 \%$ of catch are quite light (30-147 gr) and the sex ratio of males to females was 1:2. It was also revealed that approximately $35 \%$ of female species were carrying eggs (BEF/barried female).
\end{abstract}

Keywords: geospatial, fishing ground, suitability, Lancang Island, blue swimming crab.

\begin{abstract}
ABSTRAK
Rajungan di perairan Pulau Lancang terindikasi mengalami overfishing. Pemanfaatan sumberdaya rajungan merupakan tantangan besar yang memerlukan suatu skema pengelolaan yang tepat. Oleh karena itu, penelitian ini bertujuan untuk mengkaji karakteristik perairan yang sesuai untuk daerah penangkapan Rajungan ( $P$. pelagicus) secara spasial sebagai dasar penentuan kesesuaian daerah penangkapan rajungan ( $P$. Pelagicus) di sekitar Pulau Lancang, Kepulauan Seribu. Informasi karakteristik perairan yang sesuai untuk daerah penangkapan Rajungan $(P$. pelagicus) sebagaimana tujuan penelitian, merupakan upaya langkah awal perlindungan rajungan di perairan pulau Lancang, Kepulauan Seribu. Penelitian dilakukan dengan menggunakan analisis geospasial, dimana analisi geospasial merupakan salah satu tools untuk menilai kondisi eksisting lingkungan laut secara fisik yang merupakan habitat rajungan. Berdasarkan analisis spasial, hasil penelitian menunjukkan bahwa parameter lingkungan secara umum mendukung bagi pertumbuhan rajungan. Beberapa parameter seperti MPT, TDS, kecerahan, fosfat, nitrat, kedalaman dan substrat
\end{abstract}


merupakan daerah yang $100 \%$ sesuai. Parameter salinitas, DO dan suhu merupakan daerah sesuai bersyarat dan tidak sesuai bagi kehidupan pertumbuhan rajungan. Hasil pembobotan dan reklasifikasi parameter daerah perairan Pulau Lancang adalah daerah yang sesuai untuk daerah pertumbuhan rajungan. Hasil tangkapan rajungan menunjukkan bahwa $40 \%$ rajungan ditangkap dengan ukuran karapas kecil $(7-11,83 \mathrm{~cm}$ ) (tergolong ke dalam ukuran lebar karapas yang dilarang oleh pemerintah), $68 \%$ rajungan dengan bobot kecil (30-147 gram). Nisbah kelamin dalam kondisi tidak seimbang antara jantan dan betina (1: 2), dan 35\% hasil tangkapan rajungan betina dalam kondisi membawa telur (BEF/barried female).

Kata kunci: geospasial, kesesuaian daerah penangkapan, Pulau Lancang, rajungan

\section{PENDAHULUAN}

Rajungan (Portunus pelagicus) yang juga dikenal dengan nama kepiting perenang (blue swimming crab) termasuk hewan perenang aktif, tetapi saat tidak aktif hewan ini mengubur diri di dasar perairan. Sebagai hewan scavenger (pemakan bangkai), rajungan juga berburu dan menangkap hewan kecil serta binatang-binatang lain yang ada di laut dengan cara berenang di dekat permukaan (sekitar $1 \mathrm{~m}$ ) sampai kedalaman $56 \mathrm{~m}$ (Maynou and Charles 2000).

Rajungan bernilai gizi tinggi dan merupakan komoditas ekspor dengan nilai jual yang mahal dan semua bagian tubuhnya dapat dimanfaatkan. Pemanfaatan tubuuh rajungan diantaranya: daging rajungan banyak digunakan sebagai bahan baku rajungan kalengan, cangkang atau kulit rajungan dapat diolah sebagai bahan baku kosmetik serta beberapa industri lainnya (Soegiri et al. 2014).

Banyaknya manfaat rajungan ini memicu overexploitasi sehingga di beberapa daerah penangkapan rajungan yang potensial terindikasi mengalami overfishing (tangkap lebih). Pemanfaatan yang tidak terkontrol dan perubahan kondisi lingkungan perairan yang mengarah pada kerusakan habitat ditenggarai menjadi penyebab menurunnya populasi rajungan di beberapa sentra penghasil rajungan di Indonesia. Hal ini menyebabkan dikeluarkannya aturan larangan tangkap rajungan, pada ukuran dan kondisi tertentu yang tertuang pada PERMEN KP No. 1/2015.

Pulau Lancang sebagai salah satu sentra rajungan yang terletak di titik paling selatan di antara gugusan pulau lain di Kepulauan Seribu juga terindikasi mengalami overfishing (Agus et al. 2008). Ancaman overfishing telah mengemuka seiring permintaan dan tekanan lingkungan yang semakin tinggi. Akan tetapi adanya pelarangan penangkapan rajungan, menjadikan terancamnya tumpuan hidup sebagian besar nelayan di Kepulauan Seribu yang menjadikan rajungan sebagai target penangkapan utama.
Rajungan merupakan salah satu komponen perikanan skala kecil bernilai tinggi di banyak negara di daerah tropis (Nugraheni et al. 2015). Pendekatan spasial telah banyak diterapkan dalam pengelolaan perikanan skala kecil di beberapa negara (Lunn and Dearden 2006). Pengelolaan yang tidak benar dapat menimbulkan berbagai dampak yang merugikan (Yulius et al. 2014). Analisis geospasial merupakan tools yang tepat untuk menilai kondisi existing lingkungan laut secara fisik yang merupakan habitat sumberdaya hayati laut, dan berguna dalam merumuskan model perencanaan berbasis wilayah (Wright and Heyman 2008).

Pemulihan stok rajungan alami, perlu dilakukan dengan penetapan zona konservasi daerah asuhan dan mendapat dukungan dari masyarakat setempat. Apabila diterapkan, maka upaya tersebut masih bisa mengupayakan bergulirnya ekonomi lokal nelayan rajungan, selain menyokong proses ekologi penting yang dibutuhkan stok rajungan untuk kembali pulih.

Langkah awal dari upaya untuk penentuan zona konservasi membutuhkan beberapa informasi yang terkait dengan kondisi lingkungan, yang kemudian dianalisis berdasarkan literatur sebelumnya. Informasi awal berkaitan dengan kondisi lingkungan di Pulau Lancang masih minim, sehingga perlu dilakukan pengumpulan data, termasuk menggunakan analisis geospasial.

Berdasarkan uraian di atas, maka penelitian ini dilakukan untuk mengkaji karakteristik perairan yang sesuai untuk daerah penangkapan Rajungan ( $P$. pelagicus) secara spasial sebagai dasar penentuan kesesuaian daerah penangkapan rajungan ( $P$. Pelagicus) di sekitar Pulau Lancang, Kepulauan Seribu.

\section{METODE}

Penelitian ini dilaksanakan pada bulan Juni sampai dengan September 2015. Lokasi penelitian bertempat di perairan Pulau Lancang, Kecamatan Kepulauan Seribu Selatan, Provinsi 
DKI Jakarta. Secara geografis lokasi penelitian terletak pada 5053'59"-5058'43" LS dan 106 $30^{\prime}$ 00"-106039'33" BT (Gambar 1).

Data parameter lingkungan perairan sebagai data primer, data tangkapan rajungan (lokasi penangkapan, ukuran karapas, bobot individu, dan kondisi betina membawa telur) digunakan sebagai validasi peta kesesuaian, Peta Rupa Bumi Indonesia (RBI) versi digital sebagai peta dasar penentuan peta-peta tematik, hard disk untuk penyimpanan peta versi digital, serta kuisioner nelayan untuk penentuan lokasi fishing ground .

Peralatan yang digunakan untuk survei lapang adalah hand GPS (Global Positioning System) untuk mengumpulkan informasi lokasi, Map Sounder digunakan untuk mengetahui kedalaman perairan, multiparameter water quality checker untuk pengukuran kualitas air (kecerahan, suhu, salinitas, DO/Dissolved Oxygen dan $\mathrm{pH} /$ derajat keasaman), Van Dom Watersampler untuk sampel air (MPT/Muatan Padatan Tersuspensi, TDS/Total Dissolved Solids, Fosfat dan Nitrat), Grap Sampler untuk mengambil sampel sedimen, kamera digital untuk dokumentasi, perahu bermotor untuk transportasi pengambilan data lapangan, serta timbangan duduk dengan penggaris dan alat tulis untuk sampling morfometrik rajungan.

Penentuan lokasi pengamatan dilakukan dengan metode partisipatory fishing ground mapping yaitu berdasarkan informasi nelayan yang berpengalaman dan telah melakukan aktivitas penangkapan dalam waktu cukup lama (Pratiwi et al. 2014). Peta lokasi pengamatan digunakan sebagai lembar kuisioner dalam format grid dengan dimensi 2,1 $\mathrm{km} \times 2,1 \mathrm{~km}$ (Gambar 1) yang berguna untuk mengarahkan nelayan menentukan lokasi penangkapannya. Pertimbangan penggunaan sistem grid berdasarkan alat tangkap yang digunakan nelayan rajungan Pulau Lancang adalah bubu lipat yang terikat satu sama lain sehingga terbentuk satu untaian bubu dengan jarak antar bubu kurang lebih $12 \mathrm{~m}$ dengan jumlah bubu yang beroperasi antara 300-600 unit per trip (Nugraheni et al. 2015). Ini diasumsikan bahwa satu nelayan/ kelompok nelayan mewakili satu grid sebagai lokasi penangkapan rajungan.

Wawancara dilakukan saat nelayan mendaratkan hasil tangkapan ke pengumpul untuk ditimbang, dan secara simultan dilakukan pengukuran morfometrik sampel rajungan (lebar karapas, bobot, jenis kelamin dan kondisi telur). Sampling rajungan pada kelompok nelayan yang dijadikan narasumber ada 9 kelompok nelayan dan dilakukan setiap bulannya, dengan metode secara sengaja (purposive sampling).

Hasil sampling dikelompokkan menjadi 3 kelas mewakili ukuran besar, sedang dan kecil. Pengelompokan d ilakukan untuk mengetahui apakah hasil tangkapan sudah sesuai dengan anjuran pemerintah yang tertuang dalam Peraturan Menteri KKP No 1 tahun 2015, yang melarang penangkapan rajungan dengan lebar karapas $<10 \mathrm{~cm}$ dan bobot $<55$ gram.

Sampling kualitas air dilakukan pada bulan Juni 2015 (mewakili musim timur), bekerjasama dengan Tim Peneliti Rajungan Pulau Lancang-BOPTN (Bantuan Operasional Perguruan Tinggi Negeri) pada penelitian Tahap 1 tahun 2015. Lokasi sampling kualitas air dilakukan di perairan Pulau Lancang, Pulau Laki dan Pulau Bokor. Penentuan stasiun sampling dengan menggunakan metode acak terpilih (Purposive Random Sampling) dengan 15 titik stasiun. Teknik ini digunakan peneliti dengan pertimbangan-pertimbangan tertentu dalam pengambilan sampel atau penentuan sampel untuk tujuan tertentu (Teddlie et al. 2007) (Gambar 1).

Untuk mengetahui kedalaman perairan, dilakukan pemeruman lokasi penelitian dengan menggunakan fish finder. Transducer GPS dioperasikan pada frekuensi $50 \mathrm{kHz}$ dengan daya $500 \mathrm{~W}$, dan dipasang di sisi kiri kapal pada kedalaman $\pm 50 \mathrm{~cm}$ dari permukaan laut. Instalasi tersebut ditujukan untuk meminimalkan derau (noise) yang mungkin ditimbulkan akibat perputaran baling-baling kapal motor yang rotasinya berlawanan dengan arah jarum jam. Pemeruman sepanjang transek dengan kecepatan kapal \pm 5 knot. Hamburan balik sinyal yang dipindai oleh receiver-transducer menandai nilai kedalaman (z) pada titik yang telah diketahui referensi geografisnya.

Sampel kualitas air di lokasi studi diambil secara komposit, yaitu di permukaan, di kolom perairan dan dekat dasar perairan. Untuk pengukuran kecerahan, suhu, salinitas dan DO dilakukan pencatatan langsung dari angka yang tertera pada alat. Sementara untuk parameter MPT, TDS, Fosfat dan Nitrat dilakukan pengambilan sampel air laut, demikian juga dengan sampel sedimen. Sampel air dan sedimen selanjutnya dianalisis di Bagian Hidrobiologi Laut dan Laboratorium Produktivitas Lingkungan, FPIKIPB.

Data parameter lingkungan selanjutnya dilakukan interpolasi dalam bentuk peta sebaran sebagai peta tematik untuk dijadikan peta kesesuian lokasi penangkapan dengan metode pembobotan untuk tiap parameter. Pembobotan ini bertujuan untuk menentukan seberapa besar 
pengaruh suatu parameter terhadap parameter lainnya. Selain itu setiap tema akan dibagi menjadi beberapa kelas yang diberi skor berdasarkan tingkat kesesuaiannya. Sehingga pada hasil akhir akan diperoleh "nilai akhir" atau "matriks atribut" yang merupakan hasil perkalian antara bobot dengan skor kelas. Setiap kriteria dan parameter, pemberian bobot, dan skor kelas ditentukan berdasarkan studi kepustakaan, dan justifikasi dari tenaga ahli yang berkompeten di bidang perikanan, baik secara tertulis maupun secara lisan (Tabel 1). Pembobotan setiap parameter berdasarkan tingkat pengaruh atau nilai penting parameter yang bersangkutan. Nilai penting parameter dilihat dari seberapa besar bobot yang diberikan untuk penentuan skor nilai.

Interval kelas dan nilai kesesuaian daerah penangkapan ditentukan dengan menggunakan rumus (Noor 2015) :

$\mathrm{I}=\frac{\left(N_{\operatorname{maks}}-N_{\min }\right)}{\Sigma k}$

dengan:

I=Interval kelas

$\mathrm{k}=$ Jumlah kelas kesesuaian yang diinginkan

$\mathrm{N}_{\operatorname{maxs}}=$ Nilai akhir maksimun

$\mathrm{N}_{\min }=$ Nilai akhir minimum

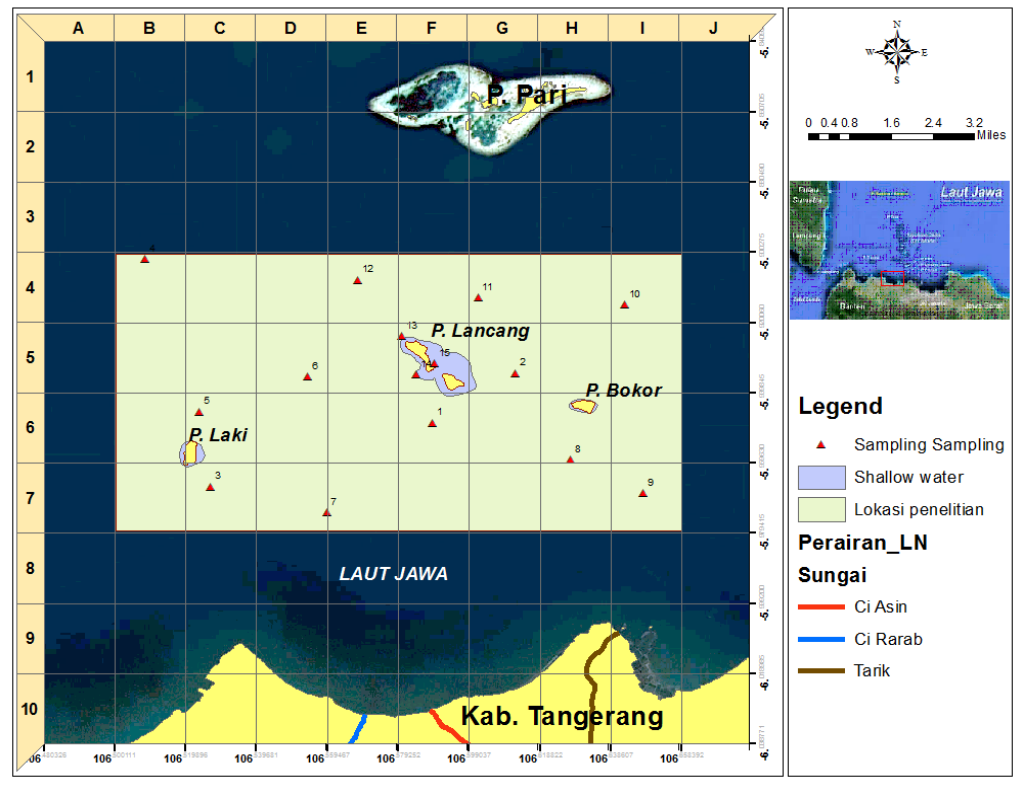

Gambar 1 Lokasi penelitian dan stasiun sampling kualitas air

Tabel 1 Penentuan Kategori Kesesuaian Area

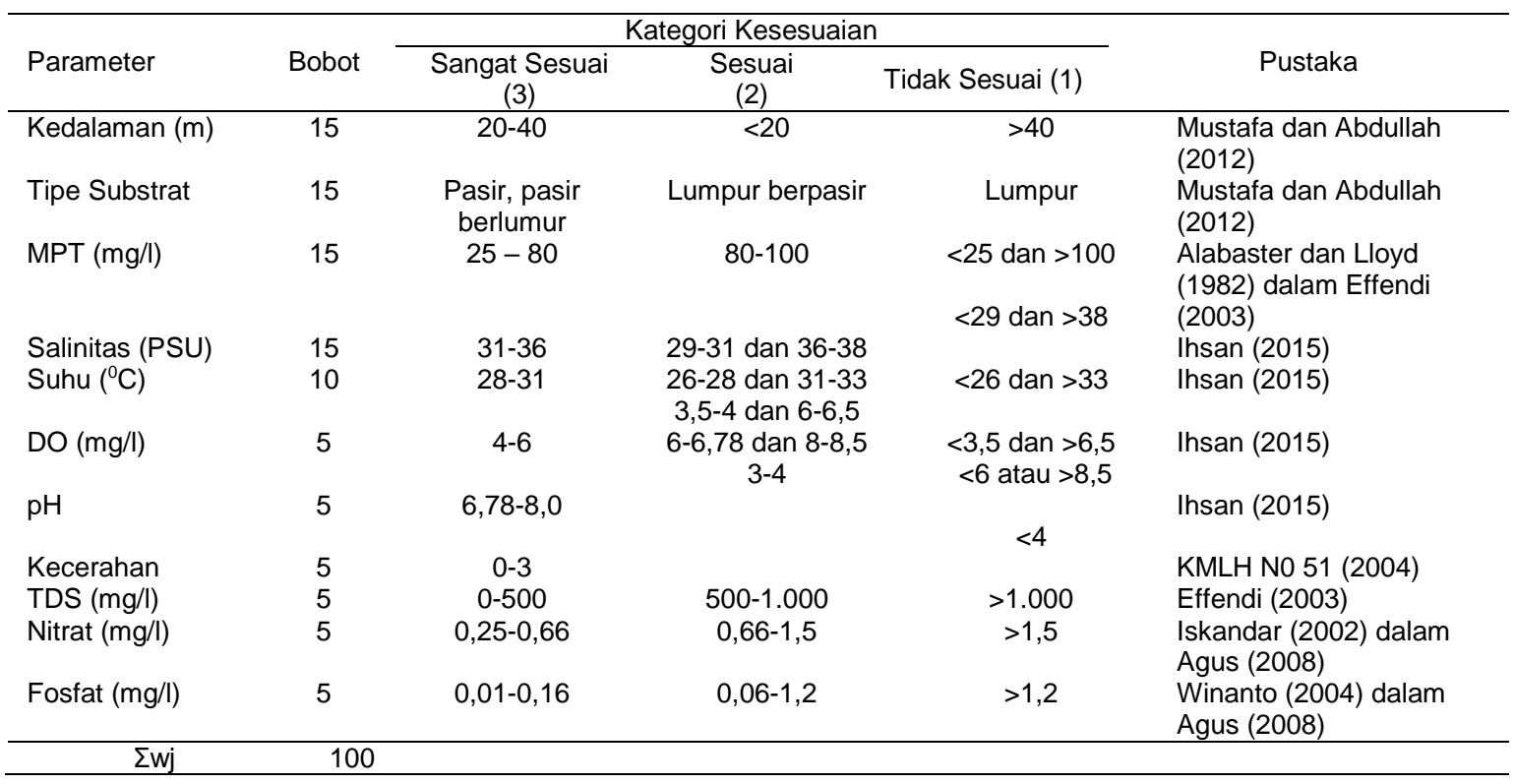




\section{HASIL DAN PEMBAHASAN}

\section{Kualitas Perairan Pulau Lancang di Juni 2015 (Musim Timur)}

Interpolasi hasil pengukuran dan pengambilan sampel air laut yang dilakukan di 15 titik stasiun terlihat sebaran spasial masing-masing parameter.

\section{Suhu $\left({ }^{\circ} \mathrm{C}\right)$}

Faktor lingkungan utama yang mempengaruhi reproduksi $P$. pelagius adalah suhu air (Nugraheni et al. 2015). Dari hasil pengukuran diperoleh nilai kisaran suhu pada selang 27,89 $29,39^{\circ} \mathrm{C}$. Secara spasial, suhu permukaan laut di barat Pulau Lancang lebih rendah daripada di tengah perairan (antara Pulau Lancang dan Pulau Laki) dan timur Pulau Lancang (Gambar 2). Tingginya suhu di bagian tengah perairan dipengaruhi oleh limpasan air sungai dari daratan Jawa, umumnya lebih hangat dibandingkan dengan di bagian barat Pulau Laki yang terpengaruh asupan massa air dari perairan terbuka yang lebih dalam. Demikian juga di bagian timur Pulau Lancang dan sekitar Pulau Bokor, terpengaruh limpasan massa air tawar dari sungai-sungai yang bermuara ke Teluk Jakarta.

\section{MPT (mg/l)}

Mutan Padatan Tersuspensi (MPT) merupakan bahan-bahan tersuspensi yang berdiameter $>1$ mikrometer yang tertahan pada saringan Millipore dengan diameter pori 0,45 mikrometer. MPT terdiri atas lumpur dan pasir halus serta jasad renik yang terutama disebabkan oleh kikisan tanah atau erosi tanah yang terbawa ke badan air.

Secara spasial kandungan MPT di perairan Pulau Lancang tidak jauh berbeda secara signifkan. Akan tetapi kondisi di selatan perairan Pulau Lancang berdekatan dengan daratan utama (main land) memiliki nilai MPT yang lebih tinggi dibandingkan dengan wilayah lainnya (Gambar 2). Hal itu memungkinkan karena adanya pengaruh masukan yang berasal dari daratan, karena selatan perairan Pulau Lancang masih dipengaruhi aktivitas yang berasal dari daratan.

\section{TDS (mg/l)}

Total Disolve Solid (TDS) merupakan parameter yang menjelaskan partikel-partikel yang terlarut di dalam air dan tidak akan bisa tersaring oleh kertas saring. TDS ini biasanya dipengaruhi oleh bahan anorganik yang berupa molekul-molekul garam yang umum ditemukan di perairan laut.

Berdasarkan sebaran spasial nilai TDS, terlihat TDS tinggi di bagian barat daerah penelitian dan rendah di bagian timur (Gambar 3). Perbedaan TDS juga terlihat di antara pulau Lancang Besar dan Lancang Kecil. Tinggi TDS di bagian barat diduga berasal dari aliran limbah daratan, sedangkan perbedaan TDS yang terlihat di Pulau Lancang Besar dan Lancang Kecil yang relatif berdekatan disebabkan kondisi Pulau Lancang Besar berpenghuni sedangkan Pulau Lancang Kecil tidak dihuni penduduk lokal (kepemilikan swasta).

\section{Kecerahan (m)}

Kecerahan perairan merupakan salah satu parameter yang mengukur tingkat kejernihan suatu perairan. Menurut Sari et al (2012), kecerahan perairan adalah suatu kondisi yang menunjukkan kemampuan cahaya untuk menembus lapisan air pada kedalaman tertentu. Pada perairan alami kecerahan sangat penting karena erat kaitannya dengan aktivitas fotosintesa. Kecerahan merupakan faktor penting bagi proses fotosintesa dan produksi primer dalam suatu perairan.

Berdasarkan data yang diperoleh menunjukkan bahwa kecerahan perairan di perairan pulau Lancang berada pada kisaran 1,375,45 m (Gambar 3). Rata-rata nilai kecerahan di perairan Pulau Lancang sebesar 2,25 m. Nilai tersebut masih di bawah nilai baku mutu kecerahan yang ditetapkan oleh KEPMENLH No. 51 Tahun 2004 yaitu sebesar $3 \mathrm{~m}$ untuk kehidupan biota laut. Penyebab nilai kecerahan perairan yang berada di bawah rata-rata ini salah satunya dikarenakan lokasi Pulau Lancang yang masih dekat dengan kawasan daratan utama dan kawasan pulau-pulau kecil disekitarnya. Secara spasial dapat diketahui bahwa kondisi kecerahan di perairan Selatan Pulau Lancang dan sekitar Pulau Laki secara umum memiliki nilai kecerahan yang rendah dibandingkan di Utara.

\section{$\mathrm{DO}(\mathrm{mg} / \mathrm{l})$}

Berdasarkan hasil pengukuran diketahui bahwa sebaran kandungan oksigen terlarut (dissolve oxygen/DO) di perairan Pulau Lancang tidak berbeda secara signifikan di tiap stasiun. Kandungan DO di permukaan laut perairan Pulau Lancang berkisar antara 5,09-9,17 mg/l. Stasiun yang memiliki kadar DO terendah terdapat di stasiun 15, yaitu hanya sebesar 5,09 $\mathrm{mg} / \mathrm{l}$. Sedangkan kadar DO tertinggi terdapat di stasiun 6 sebesar 9,17 mg/l (Gambar 4). Berdasarkan Keputusan Menteri Negara Lin- 
gkungan Hidup Tahun 2004 tentang baku mutu air laut untuk biota laut yaitu oksigen terlarut (DO), adalah >5 mg/l (As-Syakur et al. 2016). Sebaran kandungan oksigen terlarut secara spasial memiliki nilai yang relatif kecil di sekitar daratan Pulau Lancang dan Pulau Laki. Hal itu dikarenakan di sekitar daratan pulau Lancang terdapat pemukiman yang menyumbang limbah organik ke dalam perairan. Begitu juga dengan kawasan pulau Laki yang memiliki lokasi tidak jauh dari kawasan daratan utama (mainland) menyebabkan sumbangan bahan organik ke perairan cukup tinggi. Tingginya masukan bahan organik ke perairan laut berdampak kepada rendahnya nilai kandungan DO. Rendahnya bahan DO tersebut dikarenakan kandungan DO di perairan dimanfaatkan untuk mendekomposisi bahan organik yang terdapat di perairan.

\section{Salinitas (psu)}

Hasil pengukuran nilai salinitas permukaan laut di perairan Pulau Lancang tidak beragam atau homogen. Karakteristik salinitas ini disebabkan perairan Pulau Lancang tergolong pulau-pulau kecil yang tidak memiliki aliran sungai. Salinitas di perairan ini berada pada kisaran 29,8 - 31,70 psu (Gambar 4).

Sebaran spasial nilai salinitas di per-airan Pulau Lancang terlihat sekitar Pulau Lancang dan Pulau Laki memiliki nilai salinitas yang lebih rendah dibandingkan dengan selatan Pulau Lancang. Perbedaan nilai salinitas terdapat pada rentang yang tidak terlalu berbeda jauh, disebabkan perbedaan cuaca pada saat pengambilan data. Di beberapa lokasi, pengambilan sampel dilakukan pada saat hujan sehingga berpengaruh terhadap rendahnya salinitas di daerah tersebut.

\section{Fosfat (mg/l)}

Keberadaan unsur fosfat di perairan dapat menentukan kesuburan perairan tersebut. Kadar fosfat di Teluk Jakarta masih baik untuk kehidupan biota laut (Simanjuntak 2007). Di lokasi pengamatan ditemukan konsentrasi fosfat berada pada kisaran 0,013-0,09 mg/l (Gambar 5). Konsentrasi fosfat yang berlebih dapat menyebabkan terjadinya eutrofikasi. Secara spasial dapat diketahui kandungan posfat di selatan Pulau Lancang memiliki konsentrasi fosfat lebih tinggi dibandingkan dengan kawasan lainnya. Hal tersebut terjadi karena selatan perairan Pulau Lancang masih dipengaruhi oleh masukan bahan organik yang berasal dari daratan utama (mainland) yaitu kawasan Jakarta dan sekitarnya. Sumber fosfat di perairan dapat berasal dari pelapukan batuan, limbah rumah tangga seperti sabun dan detergen.

\section{Nitrat (mg/l)}

Kandungan nitrat air laut permukaan di perairan Pulau Lancang berkisar antara $<0,0009-0,5 \mathrm{mg} / \mathrm{l}$ (Gambar 5). Secara spasial dapat diketahui kandungan nitrat di selatan Pulau Lancang memiliki konsentrasi fospat lebih tinggi dibandingkan dengan kawasan lainnya. Hal tersebut terjadi karena sebelah selatan perairan pulau Lancang masih mendapatkan pengaruh masukan bahan organik yang berasal dari daratan utama (mainland) yaitu kawasan Jakarta dan sekitarnya sehingga berdampak terhadap tingginya konsentrasi nitrat di selatan Pulau Lancang. Sumber nitrat di perairan dapat berasal dari limbah rumah tangga dan pupuk pertanian yang ikut terlarut ke dalam air.

Nutrien atau unsur hara berperan sangat penting dalam menjaga kesuburan suatu perairan, terutama yang berhubungan dengan produktivitas primer perairan. Utamanya unsur hara yang terkandung di perairan laut berasal dari masukan air tawar melalui limpasan sungai yang membawa bahan-bahan organik. Selain itu juga berasal dari hasil dari proses sekresi dan degradasi organisme laut.

Kekayaan kadar nutrien suatu perairan bisa berakibat menguntungkan dan sebaliknya merugikan bagi organisme laut. Kondisi nutrien yang merugikan bagi organisme adalah jika keberadaan nutrien terlalu melimpah yang mengakibatkan spesies tertentu mengalami lonjakan pertumbuhan (blooming) dan mendominasi wilayah tersebut sehingga menyebabkan kompetisi ruang dan makanan yang sangat kuat di antara spesies organisme yang hidup di dalamnya (Rahimah 2016).

\section{Kedalaman}

Umumnya rajungan berenang dari dekat permukaan laut (sekitar $1 \mathrm{~m}$ ) sampai kedalaman 65 meter. Rerata kisaran kedalaman perairan di lokasi penelitian adalah 4-39 meter (Gambar 6). Profil dasar perairan Pulau Lancang dan sekitarnya cenderung rata, wilayah paling dangkal di sebelah Selatan pulau Laki. Kedalaman mempengaruhi distribusi ukuran rajungan pada suatu perairan (Hamid et al. 2016).

\section{Tipe Substrat}

Sebaran spasial substrat dasar perairan di sekitar perairan Pulau Lancang terdiri dari substrat pasir, pasir berlumpur dan lumpur berpasir (Gambar 6). Mayoritas substrat adalah lumpur berpasir yang meliputi kawasan sekitar selatan Pulau Lancang sampai ke utara Pulau Lancang. Tingginya konsentrasi lumpur pada 
kawasan tersebut berasal dari lumpur yang terbawa run off dari sungai. Lokasi Pulau Lancang yang sangat dekat dengan daratan utama (mainland), serta terdapat 13 sungai yang bermuara ke kawasan Teluk Jakarta. Kondisi ini menyebabkan lumpur masih terbawa hingga ke laut dalam konsentrasi yang cukup tinggi. Sebe- lah barat perairan Pulau Lancang memiliki substrat pasir berlumpur, dalam hal ini konsentrasi lumpur telah berkurang dan didominasi oleh pasir. Kawasan perairan Pulau Laki memiliki substrat dasar perairan yang didominasi oleh pasir.
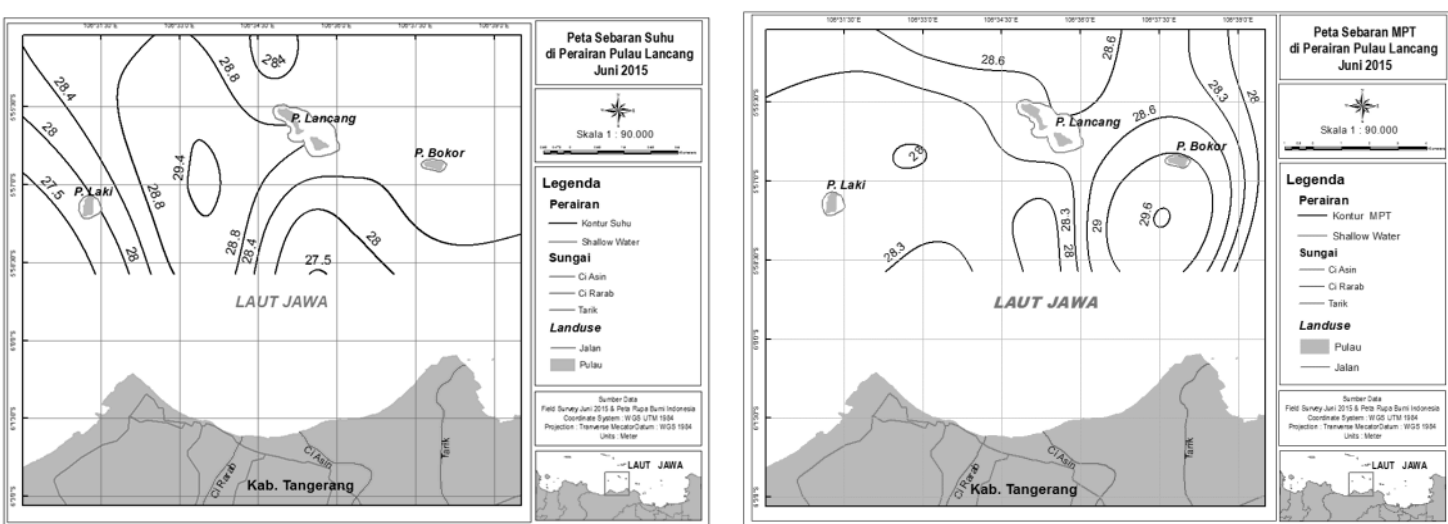

Gambar 2 Sebaran parameter suhu dan MPT di perairan Pulau Lancang pada musim timur.
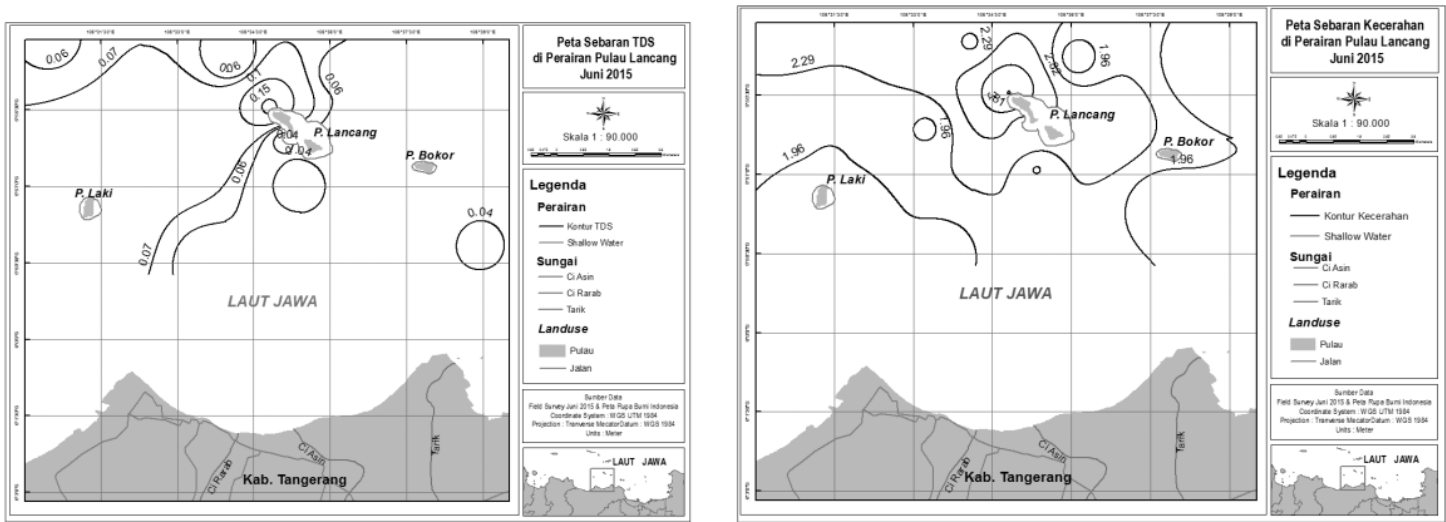

Gambar 3 Sebaran parameter TDS dan kecerahan di perairan Pulau Lancang pada musim timur.
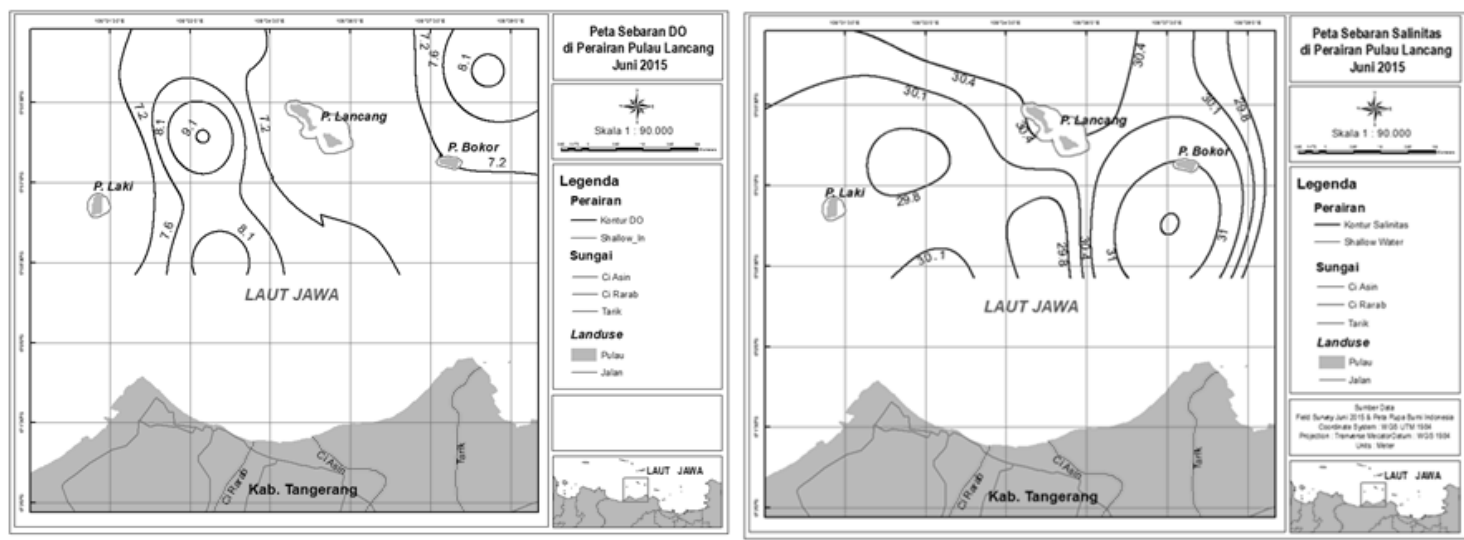

Gambar 4 Sebaran parameter DO dan salinitas di perairan Pulau Lancang pada musim timur. 

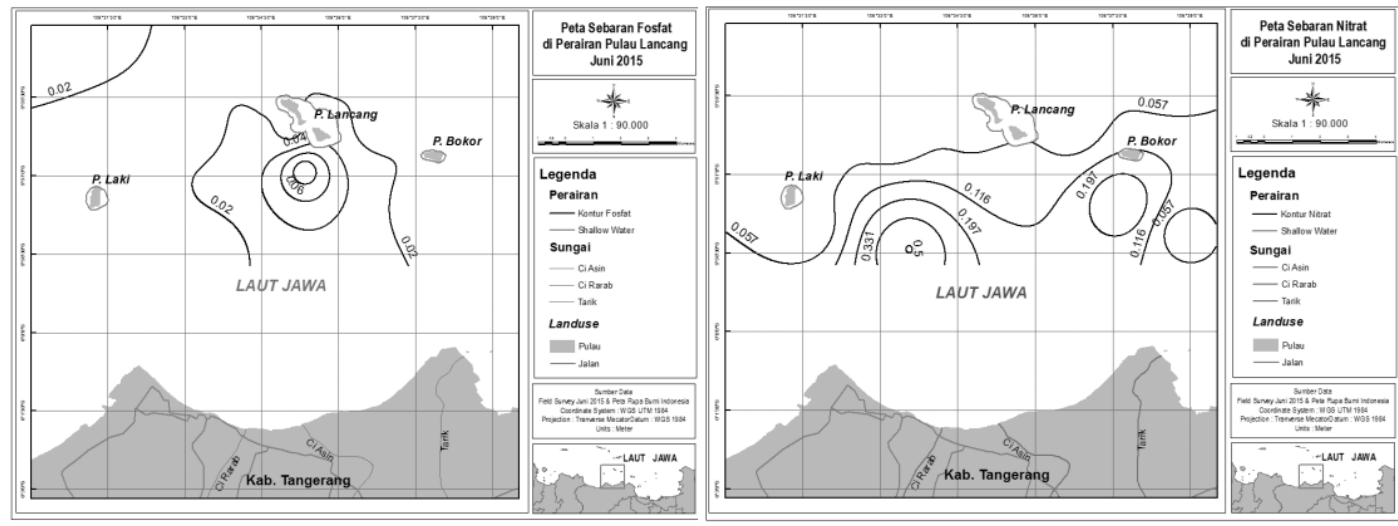

Gambar 5 Sebaran parameter fosfat dan nitrat di perairan Pulau Lancang pada musim timur.
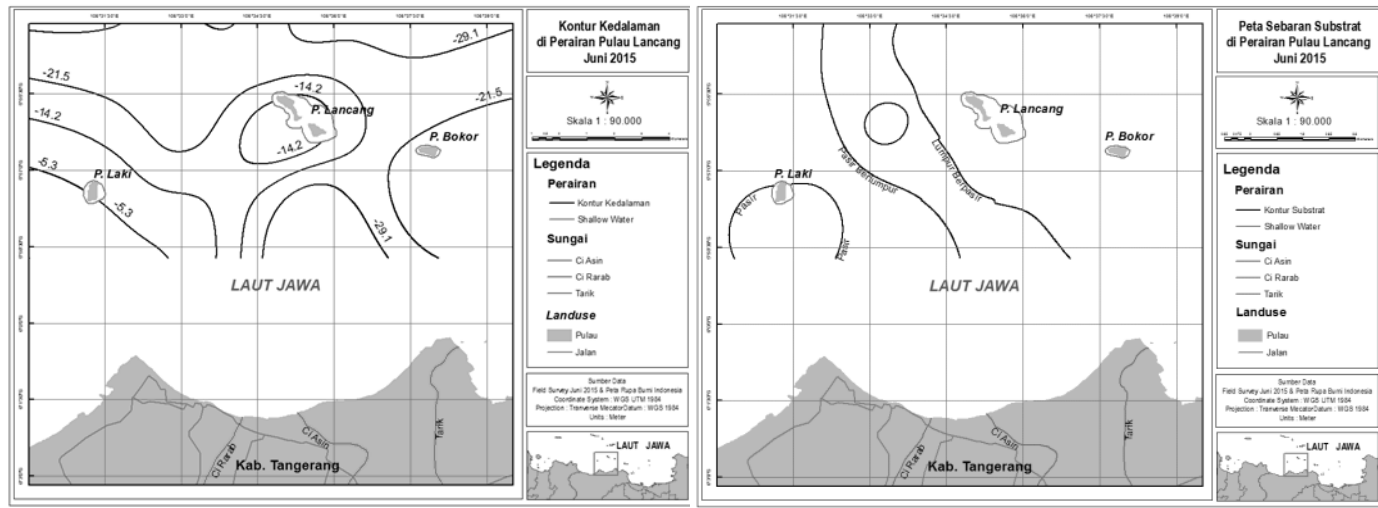

Gambar 6 Sebaran parameter kedalaman dan tipe substrat di perairan Pulau Lancang pada musim timur.

\section{Kesesuaian Daerah Penangkapan Rajungan Berdasarkan Paramater Lingkungan}

Berdasarkan hasil analisis interpolasi dan pembobotan hasil pengukuran di lapangan, dihasilkan beberapa peta tematik. Peta-peta tematik menggambarkan kondisi parameter yang mendukung sebagai daerah penangkapan rajungan di lokasi penelitian seperti MPT, TDS, kecerahan, fosfat, nitrat dan substrat. Parameter lain yang kurang mendukung sebagai daerah penangkapan rajungan di daerah ini yaitu Salinitas, DO, kedalaman dan suhu. Pada umumnya ketidaksesuain akibat aktivitas masyarakat di pulau yang berpenghuni, maupun dari aktivitas masyarakat daratan Pulau Jawa yang masuk ke perairan melalui aliran sungai yang bermuara langsung ke perairan ini.

Melalui proses tumpang susun (overlay) peta-peta tematik tersebut menghasilkan suatu peta kesesuian daerah penangkapan rajungan (Gambar 7) Terlihat kelas sangat sesuai (SS) sebagai daerah penangkapan rajungan di perairan Pulau Lancang berada menyebar di bebe- rapa bagian. Kelas SS yang terdapat hampir di keseluruhan utara lokasi penelitian. Terbentuknya daerah SS ini dipengaruhi oleh parameter salinitas dimana menurut Zairion et al. (2014) kepiting suku portunidae (swimming crabs) bermigrasi untuk memijah ke perairan yang mempunyai salinitas tinggi dan perairan lebih dalam. Kelas SS berada di antara Pulau Lancang dan Pulau Laki. Selanjutnya kelas $S$ juga terdapat di beberapa bagian antara Pulau Lancang dan Pulau Bokor. Untuk kelas tidak sesuai (TS) terdapat di sebelah barat laut Pulau Lancang. Dari pengamatan di lapangan dan hasil interpolasi kedalaman, daerah yang termasuk ke dalam kelas tidak sesuai ini, merupakan daerah yang dangkal dibandingkan dengan daerah lain.

\section{Kesesuaian daerah penangkapan berdasarkan sebaran hasil tangkapan rajungan}

Dari Gambar 8 terlihat hasil sampling ukuran lebar karapas terdiri dari $1 \%$ berukuran besar (kelas 3: 16,68-21,5 cm), 59\% berukuran sedang (kelas 2: $11,84-16,67 \mathrm{~cm}$ ) dan $40 \%$ 
berukuran kecil (kelas 1:7-11,83 cm). Secara keseluruhan hasil tangkapan dengan ukuran lebar karapas sedang dan besar masih pada ukuran yang diperbolehkan oleh pemerintah, tidak demikian dengan hasil tangkapan dengan ukuran kecil.

Bobot hasil tangkapan, $68 \%$ pada kelas 1 (30-147 gr), 28\% pada kelas 2 (148-263 gr) dan $4 \%$ di kelas 3 (264-380 gr). Dibandingkan dengan bobot yang dianjurkan pemerintah $(>80$ gr), hasil tangkapan pada kelas 1 sebagian adalah rajungan yang dilarang untuk ditangkap.

Perbandingan jenis kelamin jantan terhadap betina adalah 1:2. Hasil tangkapan didominasi oleh rajungan betina sebanyak $67 \%$ dan jantan sebanyak 33\%, sehingga nisbah kelamin rajungan di musim ini diduga tidak seimbang. Nisbah kelamin populasi digunakan sebagai indikator kemampuan suatu populasi untuk tetap bertahan melalui rekruitmen (Kamrani et al. 2010).

Untuk betina bertelur, digolongkan menjadi 2 yaitu betina yang membawa telur (Berried female) yang disingkat dengan BEF dan betina tidak membawa telur (Non Berried female) disingkat NBF. Hasil tangkapan rajungan BEF adalah $35 \%$ dan sisanya $65 \%$ adalah rajungan NBF. Rajungan yang ditangkap dalam kondisi BEF merupakan ancaman bagi kelangusungan hidup rajungan.

Hasil sampling tangkapan di musim timur di atas, kemudian di-overlay dengan kesesuaian area untuk penangkapan rajungan. Overlay ini dilakukan untuk mengetahui sebaran rajungan secara spasial. Gambar 9 memberikan informasi keberadaan rajungan dengan ukuran lebar karapas dan bobot di area tertentu.

Hasil tangkapan rajungan nelayan Pulau Lancang untuk ukuran lebar karapas 7-11,83 cm didapatkan di semua area tangkapan (kategori kecil) dengan persentasi terbesar terdapat pada area D7 mencapai angka $80 \%$ dari total tangkapan di area tersebut dan persentasi paling sedikit di area D8 yaitu $20 \%$. Selanjutnya ukuran lebar karapas 11,84-16,67 cm (kategori menengah) juga ditemukan di semua area tangkapan. Sedangkan ukuran lebar kaparas 16,68-21,5 cm (kategori besar), hanya terdapat pada 2 area yaitu B4 dan C4 dengan masing-masing persentasi tangkapan 3\% dan 5\%. Hasil tangkapan dengan ukuran karapas kategori kecil adalah ukuran karapas yang dilarang untuk ditangkap oleh pemerintah. Ini berkaitan dengan keberlanjutan sumberdaya rajungan yang apabila ditangkap dengan ukuran kecil dapat memperpendek umur rajungan yang lambat laun akan menyebabkan hilangnya sumberdaya ini dari habitatnya. Jika dilihat dari segi ekonomis, rajungan ukuran kecil memiliki harga yang jauh lebih rendah dari ukuran yang disarankan (ukuran karapas $>10 \mathrm{~cm}$ ). Sehingga ini juga langsung berpengaruh terhadap pendapatan nelayan.

Dilihat dari hasil tangkapan, perairan Pulau Lancang adalah daerah yang sesuai untuk pertumbuhan rajungan. Namun hal ini tidak ditunjang dengan pengetahuan nelayan untuk menangkap rajungan berdasarkan ukuran yang disarankan serta keberlanjutan rajungan (suitibility). Dengan adanya informasi lokasi dan ukuran tangkapan, diharapkan menjadi dasar untuk menjadikan daerah ini sebagai daerah konservasi ataupun moratorium.

Gambar 9 memberikan informasi keberadaan rajungan dengan ukuran jenis kelamin dan kondisi telur di area tertentu. Untuk perbandingan jenis kelamin hasil tangkapan rajungan di musim timur didominasi oleh rajungan betina hampir di semua area, bahkan di area D4 diperoleh hasil tangkapan $100 \%$ betina. Ini menunjukkan ketidakseimbangan nisbah kelamin jantan dan betina. Apabila kondisi ini dibiarkan terus menerus, akan menyebabkan kekurangan rajungan betina untuk dapat bereproduksi.

Hasil tangkapan rajungan dengan kondisi bertelur (BEF) berdasarkan Gambar 9, mendominasi pada musim timur di perairan Pulau Lancang. Terlihat dari 14 area tangkapan, 12 area diantaranya ditemukan rajungan yang ditangkap dalam kondisi bertelur. Persentasi betina yang bertelur ditemukan paling tinggi di area C6 dalam angka 50\%. Sementara hasil tangkapan dalam NBF (betina tidak bertelur) dengan persentasi $100 \%$ terdapat di area A6 dan D7.

Sebagian rajungan yang ditangkap di daerah memiliki ukuran yang tidak disarankan (area D7) yaitu $80 \%$ dengan ukuran karapas kecil, $100 \%$ dengan bobot rendah dan $100 \%$ rajungan betina tidak membawa telur (NBF). Diduga daerah sangat sesuai adalah daerah migrasi rajungan muda ke daerah estuaria menuju ukuran dewasa. Daerah ini disarankan sebagai daerah larang tangkap. 


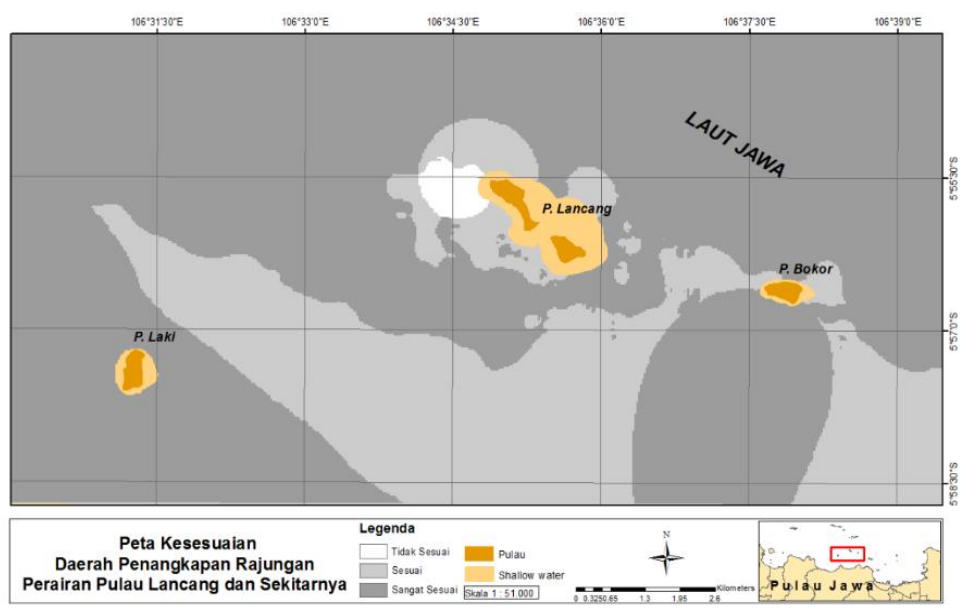

Gambar 7 Peta kesesuaian daerah penangkapan rajungan di perairan Pulau Lancang dan sekitarnya, Juni 2015 (musim Timur).
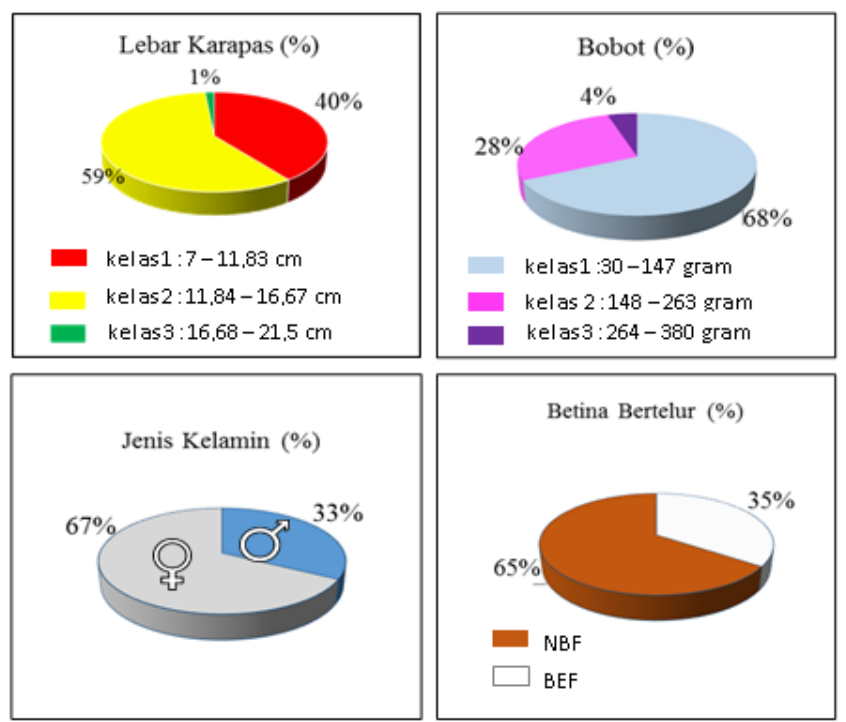

Gambar 8 Persentasi Hasil Tangkapan di Musim Timur 2015 ( $n=411)$
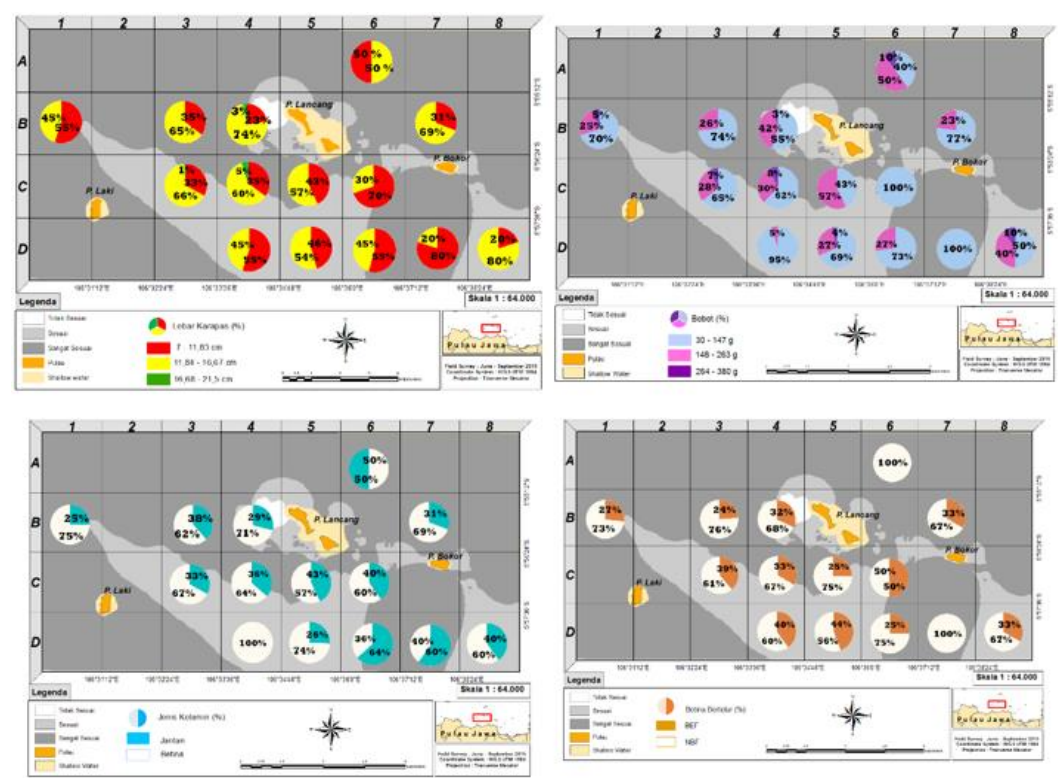

Gambar 9 Kesesuaian daerah penangkapan rajungan berdasarkan sebaran hasil tangkapan pada musim timur 2015 


\section{KESIMPULAN}

Hasil penelitian menunjukkan bahwa daerah perairan Pulau Lancang adalah daerah yang sesuai untuk daerah pertumbuhan rajungan meskipun sebagian dari kawasan Pulau Lancang tidak sesuai sebagai daerah penangkapan rajungan pada musim timur, karena $40 \%$ dari hasil tangkapan termasuk kategori karapas kecil $(7,00-11,83 \mathrm{~cm})$, dan $68 \%$ termasuk dalam kategori bobot kecil (30-147 gr) yang kemungkinan besar belum pernah bereproduksi. Di beberapa lokasi yang sesuai untuk daerah penangkapan, ditangkap rajungan dengan kondisi nisbah kelamin yang tidak seimbang antara jantan dan betina (1:2). Sebanyak 35\% hasil tangkapan rajungan betina dalam kondisi membawa telur (BEF/ barried female). Hal ini tidak menguntungkan bagi keberlanjutan (sustainability) biota tersebut.

\section{SARAN}

Untuk dapat memperoleh informasi siklus hidup rajungan selama satu tahun, diperlukan data hasil tangkapan pada musim barat dan musim peralihan. Dengan begitu, dapat melengkapi informasi yang sangat berguna bagi pemangku kepentingan untuk mengeluarkan moratorium berkaitan dengan kapan waktu yang baik serta lokasi yang disarankan sebagai daerah fishing ground rajungan.

\section{UCAPAN TERIMA KASIH}

Ucapan terima kasih kepada LPDP Kementerian Keuangan RI yang telah memberikan biaya dalam pelaksanaan penelitian ini hingga selesai. Ucapan terima kasih juga disampaikan kepada Tim BOPTN Rajungan Tahap 1 tahun 2015 atas bantuan dan kerja samanya.

\section{DAFTAR PUSTAKA}

Agus SB, T Arifin, Triyana Y, dan Sunuddin A, 2008. Kajian Pendugaan Stok Perikanan Kepiting Rajungan di Kepulauan Seribu. Suku Dinas Perikanan dan Kelautan Kepulauan Seribu.Dinas Peternakan, Perikanan dan Kelautan. Provinsi DKI Jakarta. 57 hal.

As-Syakur AR, Wiyanto DB, 2016. Studi Kondisi Hidrologis sebagai Lokasi Penempatan Terumbu Buatan di Perairan Tanjung Benoa Bali. Jurnal Kelautan. 9(1): 85-92.
Hamid A, Wardiantno, Batu DTF, Riani E. 2016. Distribusi Ukuran Spasial-Temporal dan Berdasarkan Tingkat Kematangan Gonad Rajungan (Portunus pelagicus Linnaeus 1758) di Teluk Lasongko, Buton Tengah, Sulawesi Tenggara. Jurnal OmniAkuatika. 12(2): 77-91.

Ihsan 2015. Pemanfaatan Sumberdaya Rajungan (Portunus pelagicus) secara Berkelanjutan di Perairan Kabupaten Pangkep Provinsi Sulawesi Selatan [disertasi]. Bogor: Institut Pertanian Bogor.

Juwana S, Romimohtarto K. 2000. Rajungan: Perikanan, Cara Budidaya dan Menu Masakan. Jakarta: Penerbit Djambatan.

Kamrani E, Nabi SA, Maziar Y. 2010. Stock assesment and reproductive biology of the blue swimming crab, Portunus pelagicus in Bandar Abbas Coastal Waters, Norther Persian Gulf. J. The Persian Gulf. Marine Science. 1(2): 11-22.

Lunn KE. Dearden P. 2006.Monitoring smallscale marine fisheries: an example from Thailand's Ko Chang archipelago. Fisheries Research. 77(2006): 60-71. doi:10.1016/j.fishres.2005.08.009.

Maynou F, Cartes JE. 2000. Community structure of bathyal decapod crustaceans off south-west Balearic Islands (western Mediterranean): seasonality and regional patterns in zonation. J. Ma. Biol. Ass. U.K. 80: 789-798.

Nugraheni DI, Fahrudin A, Yonvitner. 2015. Variasi Ukuran Lebar Karapas dan Kelimpahan Rajungan (Portunus pelagicus) di Perairan Kabupaten Pati.Jurnal IImu dan Teknologi Kelautan Tropis. 7(2): 493-510.

Rahimah I. 2016. Distribusi Geospasial Parameter Lingkungan dan Analisis Kesesuaian Daerah Penangkapan Rajungan (Portunus pelagicus) di Perairan Pulau Lancang, Kepulauan Seribu [tesis]. Bogor: Institut Pertanian Bogor.

Sari TEY, Usman. 2012. Studi Parameter Fisika dan Kimia Daerah Penangkapan Ikan Periaran Selat Asam Kabupaten Kepulauan Meranti Provinsi Riau. Jurnal Perikanan dan Kelautan. 17(1): 88-10.

Simanjuntak M. 2007. Kadar Fosfat, Nitrat dan Silikat di Teluk Jakarta. J. Fish. Sci. 9(2): 274-287. 
Soegiri B, Pratiwi C, Wassahua Z. 2014. Uji Coba Bubu Rajungan Tipe Kubah di Perairan Jepara. Jurnal Arioma Media Informasi Teknologi Penangkapan Ikan. 31(2): 35-42.

Teddlie C and Yu F. 2007. Mixed Methods Sampling: A Typology With Examples. Journal of Mixed Methods Research. 1(77): 1-25.

Wright DJ, Heyman WD. 2008. Introduction to the special issue: Marine and Coastal GIS for Geomorphology, Habitat Mapping, and Marine Reserves. Marine Geodesy. 31: 223-230.

doi:10.1080/01490410802466397.
Yulius, Tanto TA, Ramadhan M, Putra A, Salim HL. 2014. Perubahan tutupan lahan di pesisir Bungus Teluk Kabung, Sumatra Barat tahun 2003-2013 menggunakan system informasi geografis. Jurnal IImu dan Teknologi Kelautan Tropis. 6(2): 311318.

Zairion, Wardiatno Y, Fahrudin A, Boer M. 2014. Distribusi spasio-temporal populasi rajungan (Portunus pelagicus) betina mengerami telur di perairan pesisir Lampung Timur. Jurnal Bawal. 6(2): 95102. 